\title{
Serum complement depression during viral lower respiratory tract illness in cystic fibrosis
}

\author{
R. C. STRUNK, O. F. SIEBER, L. M. TAUSSIG, AND E. P. GALL \\ From the Departments of Pediatrics and Medicine, University of Arizona College of Medicine, Arizona \\ Medical Center, Tucson, Arizona, USA
}

SUMmaRY Cystic fibrosis (CF) patients with viral lower respiratory tract illnesses (LRI) had depressed levels of the third and fourth components of complement, which returned to normal after recovery. There was no clinical evidence of immune complex disease. CF patients with LRI and no virus isolates, CF patients in stable status, and non-CF patients with viral LRI did not have complement depression. It is postulated that antigen-antibody complex activation of complement may occur in CF patients with viral LRI.

Immune complex disease associated with serum complement $(C)$ depression has been recognized in man during hepatitis type $B$ and Epstein-Barr virus infections, dengue virus haemorrhagic fever, and subacute sclerosing panencephalitis (Oldstone, 1975). Depression of complement has not been described in other virus infections without associated immune complex disease. We have found significant depressions of the third (C3) and fourth (C4) components of complement in cystic fibrosis (CF) patients with acute viral respiratory disease.

\section{Patients and methods}

Patients. 8 CF patients were studied at the onset of an acute lower respiratory tract illness (LRI) and at follow-up after recovery. An LRI (either exacerbation or first LRI) was determined by onset or exacerbation of respiratory symptoms (cough and sputum production) plus some, but not necessarily all, of the following: lethargy, decreased appetite, fever, shortness of breath, leucocytosis, and new lung infiltrates seen on $x$-ray. Another group of $5 \mathrm{CF}$ patients was studied when they were stable with regard to their pulmonary symptoms. The clinical severity of all patients was evaluated by the NIH scoring system (Taussig et al., 1973). Routine bacteriological studies were done on all of these.

Thirteen non-CF patients, one year of age or younger, who were in hospital for acute viral LRI (croup, pneumonia, or bronchiolitis) were also studied and compared to the CF patients.

Received 7 February 1977
Complement assays. Venous blood was collected, transported in crushed ice to the laboratory, centrifuged at $0^{\circ} \mathrm{C}$, and serum stored at $-70^{\circ} \mathrm{C}$. Functional haemolytic assays of whole complement $\left(\mathrm{CH}_{50}\right)$ and $\mathrm{C4}$ were performed as previously described (Mayer, 1961; Gaither et al., 1974). C3, C5, and properdin factor B were measured by radial immunodiffusion (Mancini et al., 1965). Statistical analyses were done with the 2-tailed Student's $t$ test.

Viral studies. Specimens of nasopharyngeal, throat, and rectal swabs were inoculated in Hep-2, primary monkey kidney, and WI-38 cell cultures and viral isolates identified by standard techniques (Lennette and Schmidt, 1969).

\section{Results}

CF patients. Clinical characteristics, severity scores, and results of the studies in CF patients are given in Table 1. 4 patients yielded viral agents during LRI (group 1). The 3 patients under 6 months of age in group 1 were studied during their first LRI and the fourth was studied during an exacerbation. Infection with cytomegalovirus (CMV) and echovirus type 5 was confirmed to have been recently acquired by appropriate antibody studies. Case 1 had CMV complement-fixing antibody titre of $1: 512$ at the time of the complement studies, 2 weeks into the acute illness. In Case 3 echovirus type 5 neutralizing antibody titres rose from less than 1:8 to $1: 120$ in the acute phase and convalescent phase sera. No viruses were isolated from the remaining 4 patients with LRI (group 2) or from those with stable pulmonary 
Table 1 Clinical features, complement levels, and culture results in CF patients

\begin{tabular}{|c|c|c|c|c|c|c|c|c|c|c|c|c|c|}
\hline \multirow[b]{2}{*}{ Case no. } & \multicolumn{4}{|c|}{$\begin{array}{l}\text { Group } 1 \text { LRI,* virus positive } \\
\text { (including follow-up) }\end{array}$} & \multicolumn{4}{|c|}{$\begin{array}{l}\text { Group } 2 \text { LRI, virus negative } \\
\text { (including follow-up) }\end{array}$} & \multicolumn{5}{|c|}{ Group 3 stable status } \\
\hline & 1 & 2 & 3 & 4 & 5 & 6 & 7 & 8 & 9 & 10 & 11 & 12 & 13 \\
\hline Age (years) & $5 / 12$ & $5 / 12$ & 5 & $3 / 12$ & 11 & 5 & $2 \frac{1}{2}$ & $10 / 12$ & 25 & 19 & 15 & 10 & 13 \\
\hline \multicolumn{14}{|l|}{ Score } \\
\hline $\begin{array}{l}\text { LRI } \\
\text { Follow-up }\end{array}$ & $\begin{array}{l}64 \\
64\end{array}$ & $\begin{array}{l}72 \\
78\end{array}$ & $\begin{array}{l}82 \\
82\end{array}$ & $\begin{array}{l}70 \\
77\end{array}$ & $\begin{array}{l}56 \\
56\end{array}$ & $\begin{array}{l}65 \\
76\end{array}$ & $\begin{array}{l}42 \\
42\end{array}$ & $\begin{array}{l}88 \\
90\end{array}$ & 91 & 36 & 65 & 79 & 56 \\
\hline \multicolumn{14}{|l|}{$\mathrm{CH}_{50}$} \\
\hline $\begin{array}{l}\text { LRI } \\
\text { Follow-up }\end{array}$ & $\begin{array}{l}42 \\
57\end{array}$ & $\begin{array}{l}25 \\
40\end{array}$ & $\begin{array}{l}40 \\
48\end{array}$ & $\begin{array}{l}26 \\
39\end{array}$ & $\begin{array}{l}57 \\
44\end{array}$ & $\begin{array}{l}45 \\
40\end{array}$ & $\begin{array}{l}56 \\
60\end{array}$ & $\begin{array}{l}32 \\
34\end{array}$ & 55 & 34 & 35 & 58 & 49 \\
\hline \multicolumn{14}{|c|}{$\mathrm{C4}$ functional units/ml $\left(\times 10^{-3}\right)$} \\
\hline $\begin{array}{l}\text { LRI } \\
\text { Follow-up }\end{array}$ & 86 & 117 & 231 & 194 & 496 & 417 & 414 & 353 & 382 & 380 & 441 & 693 & 364 \\
\hline $\begin{array}{l}\text { Follow-up } \\
\text { C3 }(\mu \mathrm{g} / \mathrm{ml})\end{array}$ & 255 & 245 & 622 & 267 & 448 & 390 & 366 & 255 & & & & & \\
\hline LRI & 1023 & ND & 1122 & 910 & ND & 1301 & 2283 & 1853 & 2028 & 1698 & 1673 & 2095 & 1725 \\
\hline \multicolumn{14}{|l|}{$\operatorname{C5}(\mu \mathrm{g} / \mathrm{ml})$} \\
\hline LRI & 115 & ND & 119 & 71 & ND & 53 & 120 & 81 & 78 & 114 & 97 & 100 & 72 \\
\hline $\begin{array}{l}\text { Follow-up } \\
\text { Falor }\end{array}$ & 119 & 54 & 53 & 71 & 53 & 64 & 123 & 43 & & & & & \\
\hline \multicolumn{14}{|c|}{ Factor $B(\mathrm{mg} / 100 \mathrm{ml})$} \\
\hline $\begin{array}{l}\text { LRI } \\
\text { Follow-up }\end{array}$ & $\begin{array}{l}6.8 \\
5 \cdot 6\end{array}$ & $\begin{array}{l}\text { ND } \\
21\end{array}$ & $\begin{array}{l}40 \\
25\end{array}$ & $\begin{array}{l}18 \\
28\end{array}$ & $\begin{array}{l}\text { ND } \\
24\end{array}$ & $\begin{array}{l}5 \cdot 6 \\
18\end{array}$ & $\begin{array}{l}32 \\
\text { ND }\end{array}$ & $\begin{array}{l}22 \\
15\end{array}$ & 23 & 23 & 26 & 27 & 25 \\
\hline Culture-virus & $\begin{array}{l}\text { Cyto- } \\
\text { megalo- } \\
\text { virus }\end{array}$ & $\begin{array}{l}\text { Para- } \\
\text { influenza } \\
\text { type } 3\end{array}$ & $\begin{array}{l}\text { Echovirus } \\
\text { type } 5\end{array}$ & $\begin{array}{l}\text { Para- } \\
\text { influenza } \\
\text { type } 1\end{array}$ & $\mathrm{Neg}$ & $\mathrm{Neg}$ & $\mathrm{Neg}$ & Neg & $\mathrm{Neg}$ & Neg & $\mathrm{Neg}$ & Neg & ND \\
\hline $\begin{array}{l}\text { Culture- } \\
\text { bacterial } \dagger\end{array}$ & $\mathbf{S}, \mathbf{P}$ & $\begin{array}{l}\text { Dp, } \\
\text { Kleb, P }\end{array}$ & S, H Flu & Kleb, S & $\mathbf{P}, \mathbf{S}$ & $\begin{array}{l}\text { P, S } \\
\text { E. coli }\end{array}$ & $\mathbf{P}$ & $\begin{array}{l}\text { No } \\
\text { pathogens }\end{array}$ & $\begin{array}{l}\text { S, H Flu, } \\
\text { Strep }\end{array}$ & $\mathbf{P}, \mathbf{S}$ & $\begin{array}{l}\text { No } \\
\text { pathogens }\end{array}$ & $\mathbf{P}$ & $\mathbf{P}$ \\
\hline
\end{tabular}

* LRI = lower respiratory tract illness.

†S=Staphylococcus aureus, coagulase positive; $\mathbf{P}=$ Pseudomonas aeruginosa; $\mathbf{D p}=$ Diplococcus pneumoniae; Kleb $=$ Klebsiella pneumoniae; H Flu =Haemophilus influenzae; $E$. coli = Escherichia coli; Strep =B haemolytic streptococcus, group A.

$\mathbf{N D}=$ Not done.

disease (group 3) (see Table 1). In 3 of the 4 patients in group 2 paired acute and convalescent phase sera were examined for rises in titres of antibodies to common respiratory viruses (influenza types $\mathbf{A}$ and $B$, parainfluenza types 1,2 , and 3 , respiratory syncytial, and adenovirus group) and none were found.

The clinical severity score and the bacterial pathogens in the respiratory tract of patients in group 1 were similar to those of groups 2 and 3 . However, the $\mathrm{C} 4$ and $\mathrm{C} 3$ values in group 1 were depressed when compared to those in group $2(\mathrm{C} 4 \mathrm{P}<0.01 ; \mathrm{C} 3$ $P<0: 05)$ and group $3(P<0.001$ for both $C 4$ and $C 3)$ (see Table 2). $\mathrm{CH}_{50}$ levels were variable; the mean value in group 1 was lower than in groups 2 and 3, but not significantly so. All C5 levels were within normal range and the mean values were similar in the three groups. At follow-up 2 weeks to 5 months later when the patients had completely recovered from their LRI, the $\mathrm{C} 4$ levels in each patient in group 1 had increased to normal (Table 1) and C3 levels had increased to normal in 2 of 3 patients studied (Table 1); the mean level of $\mathrm{C} 3$ at follow-up was higher than that during LRI $(\mathrm{P}<0.05) . \mathrm{CH}_{\mathbf{5} 0}$ levels also had risen in each patient in this group. In group $2, \mathrm{CH}_{50}, \mathrm{C4}$, and $\mathrm{C} 3$ levels remained unchanged or had fallen at follow-up.
Factor B levels were variable and low levels were seen in one patient each in groups 1 and 2 . In Case 1 (group 1) factor B was low during LRI and at follow-up; in Case 6 (group 2) it was low during LRI, but had increased to normal at follow-up.

No patient developed clinical evidence of immune complex disease, such as joint or cutaneous involvement, haematuria, or proteinuria.

Non-CF patients (group 4). They were 3-12 months of age (mean 6 months). Clinical syndromes were croup 3 , bronchiolitis 5 , and pneumonia 5 . Virus isolates were 8 respiratory syncytial, 2 parainfluenza type 3, 1 cytomegalovirus, and 2 parainfluenza type 1 . A comparison of complement levels in CF patients with those in virus-positive non-CF patients is given in Table 2. $\mathrm{C} 4, \mathrm{C} 3$, and $\mathrm{CH}_{50}$ levels were not very different from those in groups 2 and 3 CF patients and in the follow-up specimens of group $1 \mathrm{CF}$ patients. However, they were higher than those in group $1 \mathrm{CF}$ patients with LRI $(\mathrm{P}<0.001$ for $\mathrm{C4}$ and C3; $\mathrm{P}<0.01$ for $\mathrm{CH}_{50}$; Table 2). $\mathrm{C5}$ levels in the non-CF patients were lower than those in group 1 CF patients with LRI $(P<0.05)$ and in CF patients with stable status $(P<0.025)$. As in the CF patients, there was no evidence of immune complex disease in the non-CF patients. 
Table 2 Comparison of complement levels in CF and non-CF patients

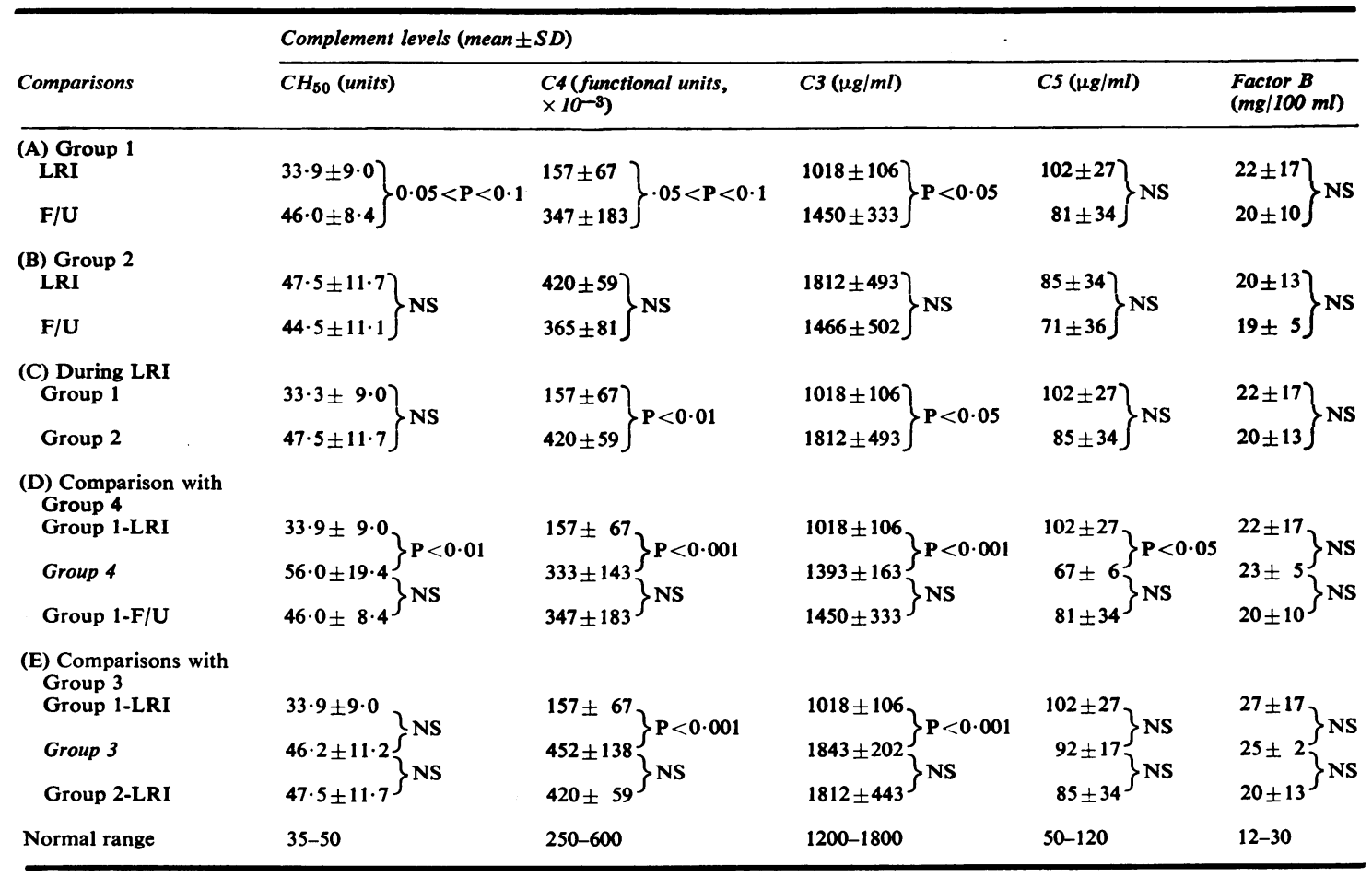

NS $=$ not significant

$\mathbf{F} / \mathbf{U}=$ follow-up

\section{Discussion}

The importance of bacterial pathogens in lower respiratory tract illnesses of $\mathrm{CF}$ patients is well known (Nadler et al., 1977). We have found multiple bacterial pathogens in the respiratory tract of CF patients with LRI and in stable status. But, viral pathogens were isolated only from among patients with LRI. This supports the preliminary findings of other workers (Deforest et al., 1972) that viral agents may cause LRIs in CF.

Several workers have studied serum complement levels in CF patients. Most have found normal or raised levels of C3 and C5 (Conover et al., 1973; Hann et al., 1974; Polley and Bearn, 1974; Wallwork et al., 1974). However, McFarlane et al. (1975) found 18 patients and 2 patients with depressed levels of C3 and C4, respectively, among 40 patients studied, but did not state whether the 2 with low $\mathrm{C} 4$ also had low C3. They also presented evidence for immune complex deposition in lungs in necropsy studies of CF patients.

Because 3 of the 4 CF patients with viral LRI were 3 to 6 months of age, age-matched controls were obtained, thereby avoiding the potential problems of age-related complement depressions in the CF patients. $\mathrm{CH}_{50}, \mathrm{C4}$, and $\mathrm{C} 3$ levels in the $\mathrm{CF}$ patients with viral LRI were significantly lower than the comparable levels in the non-CF patients. At followup, the levels in the CF patients had increased and were no longer different from the control group. A possible cause of such complement depression is activation of the classical complement pathway, though other possibilities, such as transient depressions of complement synthesis or the presence of inhibitors of complement action, have not been eliminater. but seem less likely. Levels of factor B were not consistently abnormal, indicating that the properdin pathway was probably not involved in the activation of $\mathrm{C3}$. If complement was activated by antigen-antibody complexes it is unlikely that these complexes were in the systemic circulation since there was no evidence for systemic immune complex disease. Complement could have been activated by complexes present only in the lungs. The finding of immune complexes in the lungs by McFarlane et al. is consistent with this hypothesis. One mechanism of the pulmonary injury in CF patients may thus be an immune complex deposition. It is possible that viral antigens are somehow involved in this process, either 
by being the antigen in the immune complex deposition or by producing an inflammatory process which predisposes to the interaction of bacterial or lung tissue antigen (Stein et al., 1964) with appropriate antibody. The difference between $C F$ and non-CF patients may, however, be only quantitative, related to a larger viral antigenic mass in the $\mathrm{CF}$ patient caused by inefficient clearance of infectious agents.

Viral infection and complement depression were found only in male CF patients. Because of the small sample size, we do not believe that this necessarily represents a sex-related phenomenon. The immune system does not appear to be different in male and female CF patients (Hann et al., 1974; Wallwork et al., 1974). The raised C5 levels in CF patients is consistent with other studies of complement in CF patients (Conover et al., 1973; Hann et al., 1974). The reason for these high levels is not known; it may be an acute phase reactant.

The predominance of younger CF patients with virus infection probably reflects the age-related prevalence of such infections. Clinical severity scores after recovery from LRI did not indicate discernable sequelae after one virus infection. Longitudinal studies, including detailed testing of lung function, will be required to determine if repeated virus infections produce progressive deterioration of lung function. It is notable that the first episode of LRI in 3 young CF patients was caused by a viral infection. Whether such early viral infections predispose to subsequent bacterial infection and the development of the chronic lung disease characteristic of $\mathrm{CF}$ remains to be determined.

Although the number of patients in this study is small, the complement depressions during acute viral illnesses in CF patients were large and significant. This is the first study of viral illness and associated complement depressions in CF. Additional studies will be required to extend these initial observations.

We thank Mrs. Susan Austin and Mrs. Rosella Riggins for technical assistance; Dr. T. Jacob John for editorial comments; and Sylvia Walkup for preparing the manuscript. Supported by USPHS grants H1-14136-05 and A1-12970-01, by an institutional general research support grant from the University of Arizona College of Medicine, and by
National Heart-Lung Institution Young Investigator grant no. HL-17153.

\section{References}

Conover, J. H., Conod, E. J., and Hirschhorn, K. (1973). Complement components in cystic fibrosis. Lancet, $2,1501$.

Deforest, A., Laraya-Cuasay, L., Gregory, J. E., Satz, J., and Huang, N. N. (1972). The association of viral and mycoplasma infections with lower respiratory tract disease in patients with cystic fibrosis. (Abst.) Pediatric Research, 6, 388.

Gaither, T. A., Alling, D. W., and Frank, M. M. (1974). A new one-step method for the functional assay of the fourth component (C4) of human and guinea pig complement. Journal of Immunology, 113, 574-583.

Hann, S., Holsclaw, D. S., and Shin, H. S. (1974). Complement components in cystic fibrosis. Lancet, 2, 520-521.

Lennette, E., and Schmidt, N. (1969). Diagnostic Procedures for Viral and Rickettsial Diseases. American Public Health Association, Washington D.C.

McFarlane, H., Holzel, A., Brenchley, P., Allan, J. D., Wallwork, J. C., Singer, B. E., and Worsley, B. (1975). Immune complexes in cystic fibrosis. British Medical Journal, 1, 423-428.

Mancini, G., Carbonara, A. O., and Heremans, J. F. (1965). Immunochemical quantitation of antigens by single radial immunodiffusion. Immunochemistry, 2, 235-254.

Mayer, M. M. (1961). Complement and complement fixation. Experimental Immunochemistry, p. 133. Ed. by E. A. Kabat and M. M. Mayer. Thomas, Springfield, Illinois.

Nadler, H. L., Rao, G. J., and Taussig, L. M. (1977). Cystic fibrosis. The Metabolic Basis of Inherited Disease, 4th ed. Ed. by J. B. Stanbury, J. B. Wyngaarden, and D. S. Fredrickson. McGraw-Hill, New York.

Oldstone, M. B. A. (1975). Virus neutralization and virusinduced immune complex disease. Virus-antibody union resulting in immunoprotection or immunologic injurytwo sides of the same coin. Progress in Medical Virology, 19, 84- 119.

Polley, M. J., and Bearn, A. J. (1974). Cystic fibrosis: current concepts. Journal of Medical Genetics, 11, 249-252.

Stein, A. A., Manlapas, F. C., Soike, K. F., and Patterson, P. R. (1964). Specific isoantibodies in cystic fibrosis. A study of serum and bronchial mucus. Journal of Pediatrics, $65,495-500$.

Taussig, L. M., Kattwinkel, J., Friedewald, W. D., and di Sant'Agnese, P. A. (1973). A new prognostic score and clinical evaluation system for cystic fibrosis. Journal of Pediatrics, 82, 380-390.

Wallwork, J. C., Brenchley, P., McCarthy, J., Allan, J. D., Moss, D., Ward, A. M., Holzel, A., Williams, R. F., and McFarlane, H. (1974). Some aspects of immunity in patients in cystic fibrosis. Clinical and Experimental Immunology, 18, 303-320.

Correspondence to Dr. R. C. Strunk, Department of Pediatrics, University of Arizona College of Medicine, Arizona Medical Center, Tucson, Arizona 85724, USA. 